UDK 811.163.42'625

Izvorni znanstveni članak

Prihvaćeno za tisak: 24. rujna 2021.

https://doi.org/10.22210/suvlin.2021.092.04

\author{
Zrinka Kolaković \\ Alpen-Adria Universität Klagenfurt, Institut für Slawistik \\ Zrinka.Kolakovic@aau.at
}

\title{
Actionality and affixation of biaspectual verbs in Croatian in the light of formal-functional theory of verbal aspect ${ }^{1}$
}

Slavic verbal aspect is obligatorily morphologically expressed in the infinitive and in finite verbal forms as one of two opposing values: perfective or imperfective. Additionally, Slavic languages also have biaspectual verbs. If no context is provided, the infinitive of such a verb has the potential to express both aspectual values. In order to achieve greater communicational transparency, however, native speakers sometimes use affixation to derive overtly aspectually marked verbs from biaspectual verbs. Still, not all biaspectual verbs are equally prone to affixation. Moreover, some aspectologists suggest that the type of aspectual affixation seems to depend on the inner actional properties of a verb, not only in the case of biaspectual verbs but in general.

That assumption is the starting point for this study of biaspectual verbs and their affixation. This paper addresses the following research question: Do morphologically stable (without any overtly aspectually marked derivatives) and unstable (with overtly aspectually marked derivatives) biaspectual verbs differ on the lexical level, i.e., are their actional properties significantly different?

The analysis was conducted on a sample of 38 biaspectual verbs. First, lexical meanings for each analyzed verb were compared and extracted from three dictionaries of contemporary Croatian. Second, a lexical-actional function (actional class) was assigned to each meaning according to a classification proposed within the formal-functional theory of Slavic aspect (Lehmann 1999a, 2009a). In the last step the Fisher exact test was performed. The statistical analysis suggests that the actional properties of morphologically stable and unstable biaspectual verbs differ significantly.

1 I retain full responsibility for any shortcomings of this article. At the same time, I would like to express my gratitude to the many colleagues who commented on previous drafts and presentations of this work: Sandra Birzer, Izabela Błaszczyk, Natalia Brüggemann, Jürgen Fuchsbauer, Björn Hansen, Dušica Filipović Đurđević, Zrinka Jelaska, Edyta Jurkiewicz Rohrbacher, Petar Kehayov, Volkmar Lehmann, Jurica Polančec, Dora Vuk and Veronika Wald. I would also like to thank the two anonymous reviewers for Suvremena lingvistika as well as editor Irena Zovko Dinković whose comments resulted in this substantially revised and improved version of the article. English proof-reading funding was provided by the Faculty of Humanities of the University of Klagenfurt.

The article is based on substantially revised and expanded chapters of the cotutelle $\mathrm{PhD}$ thesis Dvoaspektni glagoli - razlike između (p)opisa u priručnicima i stanja u korpusu s posebnim osvrtom na uporabu izvornih govornika (University of Regensburg/University of Zagreb), which received an award from the German Society for Croatistics (Deutsche Gesellschaft für Kroatistik) and the Embassy of the Republic of Croatia in Berlin as a $\mathrm{PhD}$ thesis thematically related to Croatian language and culture. 


\section{Introduction}

In addition to actionality, which seems to be a common feature of all languages (cf. Breu 1980: 115; Lehmann 1992a: 3f), Slavic languages also have obligatorily morphologically expressed verbal aspect. It is expressed in the infinitive and in all finite verbal forms and has two values: perfective (PFV) and imperfective (IPFV). As may be seen in Croatian examples (1a) and (1b), verbs with opposing aspectual values and the same lexical meaning are prototypically derived via aspectual affixation.

$$
\begin{array}{lcc}
\text { riješiti } & \rightarrow & \text { rješavati } \\
\text { solve.PFV.INF } & \text { solve.IPFV.INF } \\
\text { 'find an answer to, explanation for, or means of } \\
\text { effectively dealing with (a problem or mystery)' }
\end{array}
$$

(1b) čitati $\rightarrow \quad$ pročitati
read.IPFV.INF
'look at and comprehend the meaning of written
material by interpreting the characters of which
it is composed'

However, the situation is slightly more complex since all Slavic languages also have biaspectual verbs (BVs) which can take both aspectual values: PFV and IPFV. Basically, if no context is provided, like in (2a), the infinitive of such a verb has the potential to express both aspectual values, PFV and IPFV, without any further aspectual affixation. Nevertheless, only one aspectual value can be realized on the sentence level, as in (2b).
(2a) kopirati
copy.PFV.IPFV.INF
'to copy'

$\begin{array}{lllll}\text { (2b) }[. . .] i & \text { program } & \text { ce } & \text { početi } & \text { kopirati } \\ \text { and } & \text { program } & \text { FUT.3SG } & \text { start.PFV.INF } & \text { copy.IPFV.INF } \\ \text { sadržaj } & C D-a & u & \text { direktorij. } & \\ \text { content } & \mathrm{CD} & \text { into } & \text { directory } & \\ \text { '[...] and the program will start to copy the content of the } & \\ \text { CD into the directory.' } & & & \end{array}$

It is usually other verbs, the verbal category of tense, conjunctions and complementizers, as well as the way clauses are combined in coordination and subordination help detect which aspectual value is being realized. By way of illustration, in (2b) the phasal verb početi 'to start' signals that the biaspectual verb kopirati is being used in a progressive function and actually only has IPFV aspectual value. 
Yet sometimes determining the intended aspectual value is not that simple, since in Croatian most tenses allow both aspectual values. Therefore, given a lack of context or discourse signals, both aspectual values can be attributed to a single instance, like in (3a). This instance of the biaspectual verb kopirati can be interpreted as either concrete-factual or progressive, in other words as either PFV or IPFV.

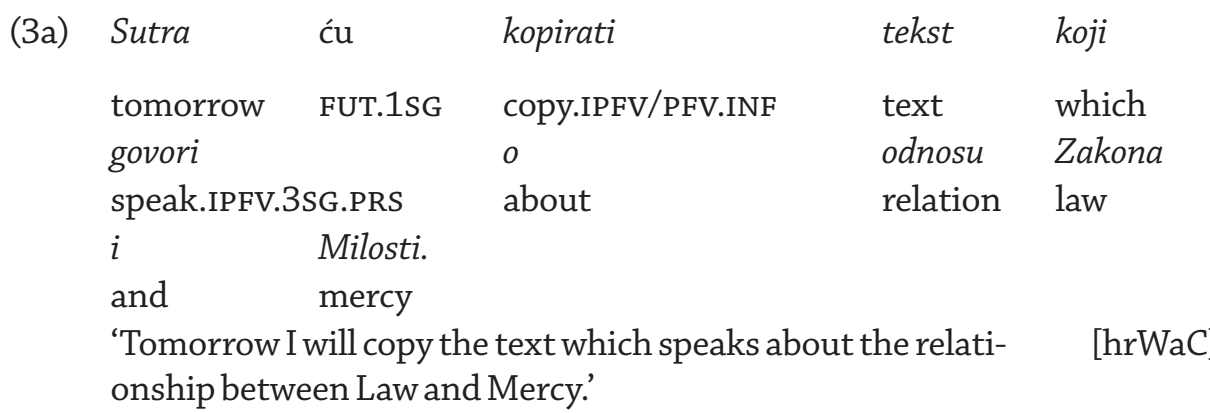

Therefore, in order to achieve communicational transparency native speakers of Slavic languages sometimes use aspectual affixation to derive overtly aspectually marked verbs from BVs (cf. Avilova 1968: 66; Silić \& Pranjković 2007: 49; Veselý 2010: 121): see (3b)

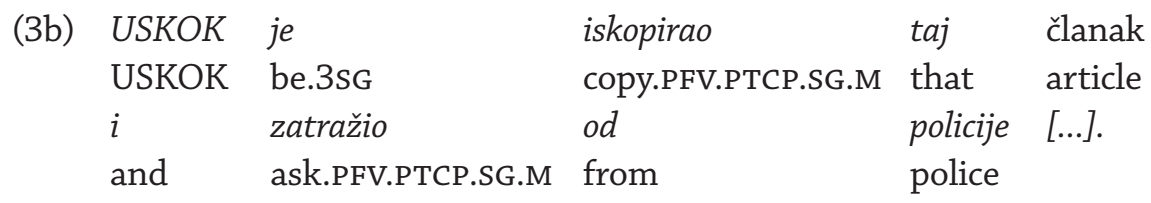

'Uskok copied that article and demanded that the police [...].' [hrWaC]

However, not all BVs are equally prone to affixation. Isačenko (1960: 145) and Maslov (1984: 87) noticed and Piperski (2018) later corroborated that some BVs tend more to the PFV, and others to the IPFV pole. In addition, it has been suggested in the aspectological literature that in general, the type of aspectual affixation highly depends on the inner actional properties of a given verb (Breu 1980, 1985, 1994; Janda 2007a, 2011, 2012b; Lehmann 1999a, 2009a, 2009b).

Although affixation of biaspectual verbs in Slavic languages has attracted considerable attention in the aspectological literature (e.g., Avilova 1968; Berger 2011; Car 1934; Čertkova 1996; Čertkova and Čang1998; Dickey 2012; Donchenko 1971; Gladney 1982; Horecký 1957; Isačenko 1960; Ivanova 1964; Jászay 1999; Kopečný 1962; Korošec 1972; Lazić 1976; Magner 1963; Mučnik 1966; Nübler 2002; Piperski 2018; Plotnikova 1971; Schoorlemmer 1995; Smiešková 1961; Šeljakin 1983; Švedova 1980; Toops 1992; Veselý 2010), the semantic, morphological and syntactic triggers of the phenomenon are seriously understudied. Moreover, to my best knowledge, the impact of actionality on aspectual affixation of biaspectual verbs has not to date been empirically studied in any Slavic language. 
The present paper is empirically oriented. Section 2 presents the formal-functional theory of Slavic aspect (Lehmann 1999a, 2009a, 2009b), actional types of verbal lexemes and how actional properties affect aspectual morphology and derivation of aspectual partners. Section 3 summarizes the discussion on the importance of semantic factors for biaspectuality and presents the research hypothesis. The choice of data and the collection process are explained in Section 4, while Section 5 describes the results in detail. This is followed by the final Section 6, which draws conclusions and offers suggestions for future research.

\section{Formal-functional theory of Slavic aspect}

\subsection{Compositional nature of Slavic aspect}

Many aspectologists have observed that various factors contribute to the realization of (im)perfective aspectual value of a verb in a given utterance. However, most linguists find it difficult to offer an explanation of the highly complex interplay of these factors in the form of one integral theory of Slavic aspect. In this respect, Lehmann's formal-functional theory qualifies as a rather successful attempt to integrate the highly complex interaction of lexical (actional), morphological, sentential and textual factors into one complex theory of verbal aspect (cf. Lehmann 1999a, 2009a). In this theory, Slavic aspect has a firm lexical base (lexical level) and a functional composition, ${ }^{2}$ see Table 1 (cf. Lehmann 2009a: 18f, 20, 36).

\begin{tabular}{|c|c|c|}
\hline Level & \multicolumn{2}{|c|}{ Function } \\
\hline $\begin{array}{l}\text { Textual level } \\
\text { (Category: taxis) }\end{array}$ & \multicolumn{2}{|c|}{$\begin{array}{l}\text { narrative sequence, parallelism } \\
\text { incidence, co-incidence }\end{array}$} \\
\hline $\begin{array}{l}\text { Sentential level } \\
\text { (Category: } \\
\text { aspectual sentential } \\
\text { function) }\end{array}$ & $\begin{array}{l}\text { concrete-factual function } \\
\text { summary function } \\
\text { exemplary function }\end{array}$ & $\begin{array}{l}\text { iterative function } \\
\text { stative function } \\
\text { general-factual function } \\
\text { progressive function }\end{array}$ \\
\hline $\begin{array}{l}\text { Morphological level } \\
\text { (Category: PFV and } \\
\text { IPFV aspect) }\end{array}$ & $\begin{array}{l}\text { dati }_{\mathrm{PFV}} \text { 'to give' } \\
\text { zaplivati }_{\mathrm{PFV}} \text {, otplivati }{ }_{\mathrm{PFV}} \\
\text { pogledati }_{\mathrm{PFv}} \text {, odgledati } \\
- \\
\text { doznati }_{\mathrm{PFV}}\end{array}$ & $\begin{aligned} \rightarrow & \text { davati }_{\mathrm{IPFV}} \\
\leftarrow & \text { plivati }_{\mathrm{IPFV}} \text { 'to swim' } \\
\leftarrow & \text { gledati }_{\mathrm{IPFV}} \text { 'watch' } \\
& \text { značiti }_{\mathrm{IPF}} \text { 'to mean' } \\
\leftarrow & \text { znati }_{\mathrm{IPFV}} \text { 'to know' }\end{aligned}$ \\
\hline $\begin{array}{l}\text { Lexical level } \\
\text { (Category: lexical- } \\
\text { actional function) }\end{array}$ & \multicolumn{2}{|c|}{$\begin{array}{l}\text { telic lexemes (da- 'give', zahvali- 'thank') } \\
\text { atelic dynamic lexemes (pliva- 'swim', drijema- 'nap') } \\
\text { diffuse lexemes (glača- 'iron', gleda- 'watch') } \\
\text { stative lexemes (znači- 'mean', zna- 'know') }\end{array}$} \\
\hline
\end{tabular}

Table 1. Lexical base of aspect and its functional composition

2 In Croatian aspectological literature the compositional nature of verbal aspect can be inferred from illustrative observations about the lexical legs, grammatical head and semantic belly of aspect (cf. Kravar 1980: 17). 
According to this theory, at the morphological level in principle almost any lexical meaning of a verb can be expressed with both aspectual values: IPFV and PFV (Lehmann 1999a: 215). This is made possible by grammatical affixation: verbs with the opposite aspectual value are derived from base verbs (without aspectual affixes) (Lehmann 2009a: 2). Hence the grammatical category of verbal aspect is seen as a grammatical and derivational category (cf. Lehmann 2009a: 2). Consequently, an aspectual partner (often called an aspectual pair in traditional aspectology) is considered to be a grammatical derivative.

This theory certainly offers new and original solutions to many complex and unsolved aspectological problems. Nevertheless, due to lack of space, the goal of Section 2 and 3 is only to present and apply the theory to Croatian on the lexical and, to a limited extent, on the morphological level.

\subsection{Slavic aspect on the lexical level}

\subsubsection{Telicity}

Telicity, with its two poles: telic and atelic, encodes information about an inner boundary. In other words, it signals whether the situation denoted by the lexical meaning can exhaust itself in the sense that after reaching such a boundary any continuation is completely ruled out (Lehmann 2009a: 9). Thus, lexical meanings with an inherent internal boundary are telic (e.g., $d a-$ 'let someone have something free of charge') as opposed to atelic ones, which have no such boundary (e.g., drijema- 'sleep lightly (be half-asleep)') (Lehmann 2009a: 9). Atelic verbal meanings imply homogeneity. This means that the lexical meaning can refer to any part of the verbal situation. Moreover, it presupposes that homogeneous atelic situations can be arbitrarily shortened or prolonged without any implications for the lexical meaning (Lehmann 2009b: 528).

\subsubsection{Situational shape}

Situational shape (Germ. Situationsgestalt) is contingent on the internal structure of a verbal situation denoted by the lexical meaning, and its nature is defined by means of the phase (Lehmann 1999a: 217; Lehmann 2009b: 529).

Taking this into account, some lexical meanings refer to verbal situations which are conceptualized as a single whole and bounded, as if they were built of (only) one phase (e.g., da- 'let someone have something free of charge') (Lehmann 1993: 276; Lehmann 1999a: 218; Lehmann 2009a: 8). Such situations are realized within the timeframe of the psychological now3 (Germ. Psychisches Jetzt) (Lehmann 1992a:

3 The psychological now as a concept in the formal-functional theory is based on studies in cognitive psychology, such as those conducted by E. Pöppel (1985). In Lehmann's theory the term psychological now refers to a time span no longer than three seconds. Perceived or experienced units are grasped as one currently existent situation within the time span of the psychological now (cf. Janik 2008: 278). 
17; Lehmann 2010: 85). In simplistic terms, this means that based on extralinguistic factors, parts of a situation not longer than three seconds can be merged into one bounded phase. Heterogeneous lexical meanings which involve some kind of change in the state of affairs are perceived as single-phase situations (Lehmann 1993: 276). This type of situational shape is called an event (Germ. Ereignis).

However, some situations go beyond the time span of the psychological now and are perceived as situations consisting of more than one phase (e.g., drijema'sleep lightly (be half-asleep)') (Lehmann 1992a: 17; Lehmann 2010: 86). In other words, situations denoted by homogeneous lexical meanings have a beginning, a middle and an end (Lehmann 1993: 277). In the formal-functional theory of aspect, this type of situational shape built of more than one phase is called a course (Germ. Verlauf) (cf. Lehmann 1992a: 17; Lehmann 2010: 86).

In addition to lexical meanings denoting the event and the course, there are also meanings which denote verbal situations without sensorimotorically detectable boundaries (e.g., znači- 'carry, have a meaning') (Lehmann 1992a: 16). As they have no such boundaries, these situations cannot be attributed to any phase. In other words, they are not identified as dynamic, so the time frame of the psychological now is not applicable (Lehmann 2010: 86). The formal-functional theory of aspect calls this type of situational shape stative (Germ. stative Situation). Stative situations and course-shaped situations share some common features - they are both homogeneous and durative. However, unlike courses, stative situations have no phases (Lehmann 1992a: 3; Lehmann 2009a: 8).

Finally, there are also lexical meanings with blurred telicity ${ }^{4}$ and consequently blurred situational shape. Depending on context, the lexical meaning of such lexemes allows them to be realized as either telic or atelic, i.e., in a verbal situation they can take the shape of an event or of a course (e.g., pisa- 'mark letters or other symbols on a surface, typically paper') (Lehmann 1999a: 218; Lehmann 2009a: 9). Whether a diffuse lexical meaning will be realized as telic (event-type situational shape) or atelic (course-type situational shape) depends in the first place on complements (Lehmann 2009b: 531). With complements in the singular and quantified complements, lexemes such as pisa- 'write' and pjeva- 'sing' are realized as telic and take the situational shape of an event (Lehmann 2009b: 531), see the example presented in (4a). On the other hand, with arguments of indefinite quantity or noun phrases in the plural, they are realized as atelic and take the situational shape of a course (Lehmann 2009b: 531), see the example presented in (4b).

$\begin{array}{llll}\text { (4a) } & {[. . .] \text { Pišem Vam }} & \text { dva } & \text { pisma. } \\ & & & \\ & \text { write.IPFV.PRS1sG you two letters } \\ & {[. . .] \text { Iam writing two letters toyou.' }} & \end{array}$

$[\mathrm{hrWaC}]$

4 The fact that telicity can stay blurred has also been noted by other aspectologists such as Gehrke (2002) and Janda (2011). 
(4b)

[...]Pišem Vam pisma.

write.IPFV.PRS1SG you letters

'[... I I am writing letters to you.'

This type of underspecified situational shape is called diffuse (Germ. diffuse Gestalt) in the formal-functional theory.

\subsubsection{Interplay of telicity and situational shape}

Telicity and situational shape are highly intertwined. As may be seen in Table 2 (cf. Lehmann 2009a: 11f) below, they are arranged in clusters. By default, telic lexical meanings imply the situational shape of an event. In contrast, atelic lexical meanings involve a stative or course-type situational shape (Lehmann 2009a: 11).

\begin{tabular}{|l|c|l|l|l|}
\hline $\begin{array}{c}\text { Lexical level } \\
\text { (Lexeme: } \\
\text { LAF) }\end{array}$ & Telicity & & $\begin{array}{c}\text { Situational } \\
\text { shape }\end{array}$ & $\begin{array}{c}\text { Morphological level } \\
\text { (Lemma: Aspect) }\end{array}$ \\
\hline da- & telic & $\leftrightarrow$ & event & dati 'to give' \\
\hline pliva- & atelic (dynamic) & $\leftrightarrow$ & course & plivati 'to swim' \\
\hline znači- & atelic & $\leftrightarrow$ & stative & značiti 'to mean' \\
\hline gleda- & (a)telic & $\leftrightarrow$ & diffuse & gledati 'to watch' \\
\hline
\end{tabular}

Table 2. Lexical-actional function

These default lexical-actional clusters can be changed on the morphological level. However, only the situational shape can be changed, while telicity remains unchanged (Lehmann 2009a: 11).

\subsubsection{Lexical-actional function and actional types of lexemes}

As already stated in Section 1, actionality - coded in the lexical root of a verb - is a feature common to all languages (cf. Breu 1980: 115; Lehmann 1992a: 3f). Depending on the actional properties of the lexical root most linguists, including Lehmann (1999a, 2009a), distinguish four major lexeme groups.5, 6

5 In principle, all classifications boil down to actional features such as (a)telicity, durativity, dynamics and phasality (cf. Comrie 1976: 41-51; Filip 2012: 721).

6 One of the best-known classifications of (English) lexemes according to their actional properties was developed by American philosopher of language Z. Vendler (1957). In his typology he distinguishes achievements, accomplishments, activities and states. 
Before going further, it is important to emphasize that according to the formal-functional theory the concept of verbal lexeme denotes only one lexical meaning of a lexical base plus variables for grammatical affixes including aspectual affixes (Lehmann 2009a: 12; cf. Apresjan 1995a-b). ${ }^{7}$ This is exemplified in (5) by the verbal lexeme da- 'give'. The lexical meaning of this lexeme corresponds to exactly one of the many meanings of the lemma dati 'to give'. 8,9

$$
\begin{array}{lc}
d a- & \text { dati } \\
\text { give.LEXICAL.BASE } & \text { give.PFV.INF } \\
\text { 'prepustiti što komu dobrovoljno, bez naknade' } \\
\text { 'let someone have something free of charge' }
\end{array}
$$

The verbal lexical base contains lexical meanings and consequently actional properties. Lehmann (2009b:538) gives an account of these under the term lexicalactional functions (Germ. Lexikalische Aktionale Funktionen). Such functions are a fundamental criterion for the classification of lexeme types. The primary features of lexical-actional functions (LAFs) are telicity and situational shape (Lehmann 2009a: 11), as presented in Sections 2.2.1 and 2.2.2 As may be seen in Table 1, in the formal-functional theory the basic verbal lexeme types are telic, atelic dynamic, stative and diffuse (Germ. Ereignislexeme, Verlaufslexeme, Stativa, aktional diffuse Lexeme). ${ }^{10}$ The lexeme presented in (5) is classified as telic in the formal-functional theory of Slavic aspect. In the next subsection a detailed classification of lexeme types as well as explanations of its criteria follow.

\subsubsection{Detailed classification of lexeme types}

As already stated in the previous subsection, in the formal-functional theory the verbal lexeme types are telic, atelic dynamic, diffuse and stative. As may be seen in Tables 3-6 (cf. Lehmann 1999a: 231; Lehmann 2009a: 18f) each of them is fur-

7 The term lexeme variant denotes a contextually caused functional difference within the same lexical meaning (Lehmann 1999a: 227).

8 In the case of polysemy, a lexical base contains more than one lexical meaning and consequently more than one lexeme. In such a case, in the formal-functional theory an index is usually used to distinguish lexemes which share the same lexical base (e.g., $d a_{1}-$ 'give,' and $d a_{2}-$ 'give ${ }_{2}$ ').

9 It should be noted that this is not a lexicographic paper. It does not aim to establish how lexical meanings of polysemous lemmas should be represented. The lexical meanings presented are the result of a comparison of meanings listed in Matasović and Jojić (2002), Jojić et al. (2015) and Birtić et al. (2013) and their sole purpose is to illustrate how lexemes are classified according to the formal-functional theory of verbal aspect.

10 In the formal-functional theory verbal lexeme types are named according to the actional function of the situational shape. Hence, there are event, course, stative and diffuse lexemes (cf. Lehmann 1999a: 228; Lehmann 2009a: 12f). I personally find this solution somewhat unfortunate since situational shape can be changed above the lexical level. In fact, situational shapes of aspectual derivatives very often differ from situational shapes that were the default in LAFs of the lexical base. Therefore, to avoid any confusion in this paper I primarily use telicity to refer to verbal lexeme types. In order to distinguish between atelic lexemes, I rely on stativity, i.e., situational shape. 
ther divided into two subtypes. It should be noted with regard to this that the lexical meanings of some lexemes involve an observable change in the state of affairs, or (potentially) an observable change in the dynamics of the situation denoted by it (cf. Lehmann 1999a: 230ff). This, however, does not hold for all lexical meanings (cf. Lehmann 1999a: 230ff). As will become evident in the following paragraphs, the subclassification of telic, atelic dynamic, and diffuse verbal lexemes is based precisely on these features.

By default, telic verbal lexemes have the situational shape of an event and their meanings refer to a single integral phase of a verbal situation (Lehmann 1999a: 228). They are comparable to achievements and accomplishments in Vendler's (1957) classification (cf. Lehmann 1999a: 228). As the examples presented in Table 3 suggest, lexical meanings of telic transformative lexemes (e.g., $d a-$ 'give' and stavi- 'put') involve a sensorimotorically noticeable change in the state of affairs (cf. Lehmann 1998: 297). By contrast, lexical meanings of telic conclusive lexemes (e.g., uključi- 'join' and zahvali- 'thank') do not implicate perceptible change in the state of affairs, but rather a certain effect (Lehmann 1999a: 230ff). Speech, mental and social act verbs are typical representatives of the latter lexemes (Lehmann 1998: 298ff).

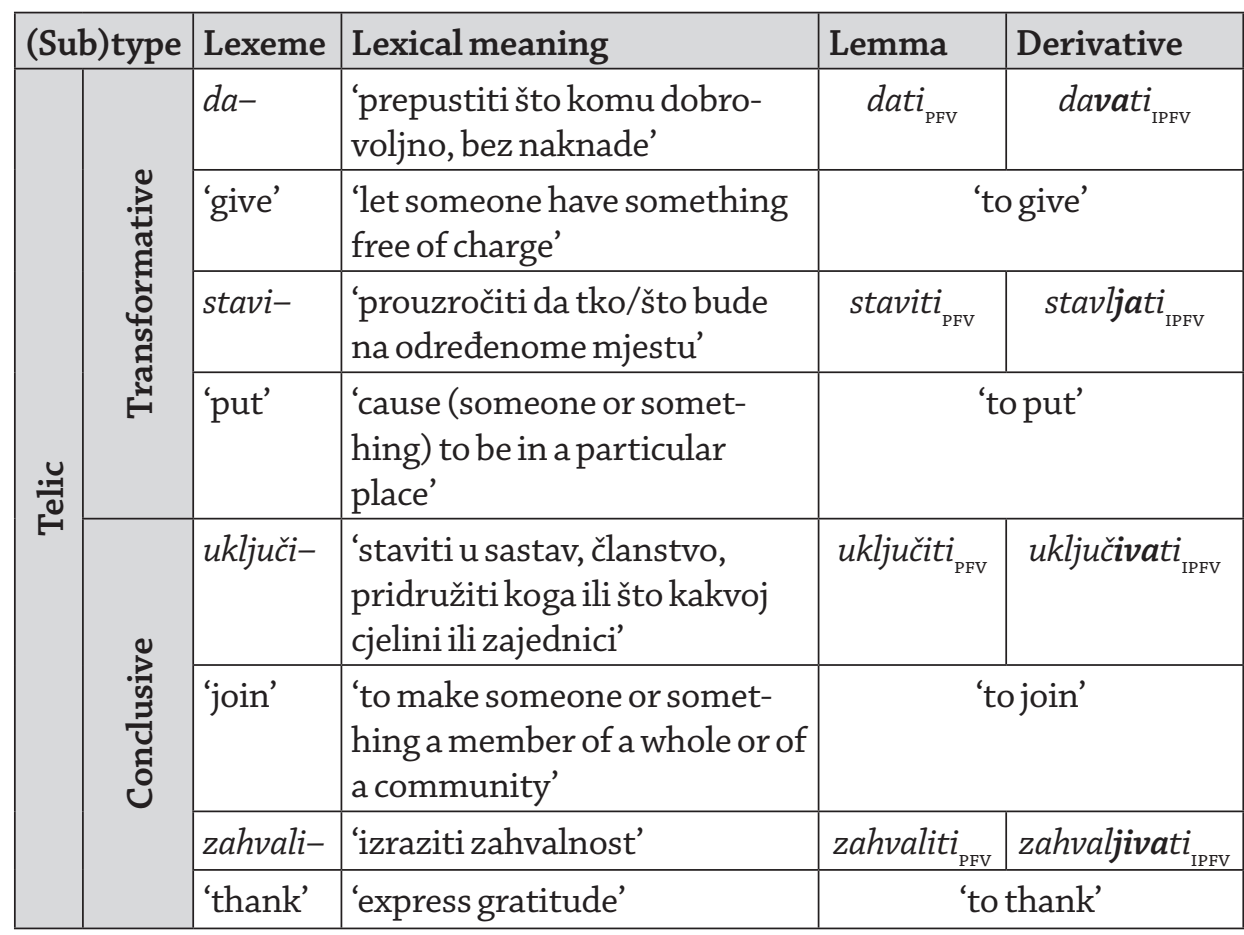

Table 3. Telic lexeme subtypes 
By default, atelic dynamic lexemes have the situational shape of a course and their meanings refer to any of multiple phases of a verbal situation (Lehmann 1999a: 228). They are comparable to Vendler's (1957) activities (cf. Lehmann 1999a: 228). As examples presented in Table 4 illustrate, the lexical meanings of some atelic dynamic lexemes (e.g., plovi- 'sail' and pliva- 'swim') are compatible with a potential indication of a noticeable change in the internal dynamics of a given situation. These are called atelic mutative lexemes (Lehmann 1999a: 230). There are also atelic dynamic lexemes whose meanings refer to situations which do not involve any change in internal dynamics (e.g., drijema - 'nap' and zvoni- 'ring') (Lehmann 1999a: 230). In the formal-functional theory the latter are labelled atelic decursive lexemes (Lehmann 1999a: 230).

\begin{tabular}{|c|c|c|c|c|c|}
\hline \multicolumn{2}{|c|}{ (Sub)type } & Lexeme & Lexical meaning & Lemma & Derivative \\
\hline \multirow{8}{*}{ 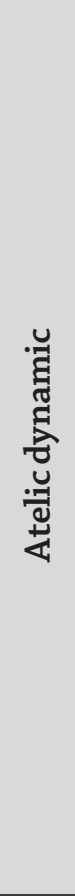 } & \multirow{4}{*}{ 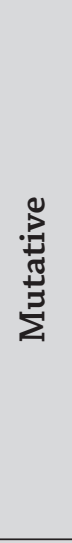 } & plovi- & $\begin{array}{l}\text { 'kretati se po površini vode u } \\
\text { određenom smjeru' }\end{array}$ & ploviti $_{\mathrm{IPFV}}$ & $\begin{array}{l}\text { zaploviti }_{\mathrm{PFV}} \\
\text { otploviti }_{\mathrm{PFV}}\end{array}$ \\
\hline & & 'sail' & $\begin{array}{l}\text { 'move along the surface of the } \\
\text { water in a particular directi- } \\
\text { on' }\end{array}$ & \multicolumn{2}{|c|}{ 'to sail' } \\
\hline & & pliva- & $\begin{array}{l}\text { 's pomoću potrebnih pokreta } \\
\text { tijela kretati se po površini } \\
\text { vode' }\end{array}$ & plivati $_{\mathrm{IPFV}}$ & $\begin{array}{l}\text { zaplivati }_{\mathrm{PFV}} \\
\text { otplivati }_{\mathrm{PFV}} \\
\text { (poplivati }_{\mathrm{PFV}} \text { ) }\end{array}$ \\
\hline & & 'swim' & $\begin{array}{l}\text { 'propel the body through } \\
\text { water by using the necessary } \\
\text { body movements' }\end{array}$ & \multicolumn{2}{|c|}{ 'to swim' } \\
\hline & \multirow{4}{*}{ 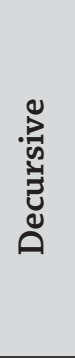 } & $\begin{array}{l}\text { dri- } \\
\text { jema- }\end{array}$ & $\begin{array}{l}\text { 'spavati polusnom, laganim } \\
\text { snom' }\end{array}$ & drijemati $_{\mathrm{IPFV}}$ & $\begin{array}{r}\text { zadrijemati }_{\mathrm{PFV}}, \\
\text { odrijemati }_{\mathrm{PFV}}\end{array}$ \\
\hline & & 'nap' & 'sleep lightly (in half-sleep)' & \multicolumn{2}{|c|}{ 'to nap' } \\
\hline & & zvoni- & $\begin{array}{l}\text { 'proizvoditi zvonjavu, oglaša- } \\
\text { vati se zvonjavom' }\end{array}$ & zvoniti $_{\mathrm{IPFV}}$ & $\begin{array}{l}\text { zazvoniti }_{\mathrm{pfv}} \\
\text { odzvoniti }_{\mathrm{PFV}}\end{array}$ \\
\hline & & 'ring' & $\begin{array}{l}\text { 'make a clear resonant or vi- } \\
\text { brating sound' }\end{array}$ & \multicolumn{2}{|c|}{ 'to ring' } \\
\hline
\end{tabular}

Table 4. Atelic dynamic lexeme subtypes

Since the lexical meanings of not only the former, but also of the latter atelic dynamic lexemes imply a multiphase internal structure, they are both subsumed under atelic dynamic lexemes and not stative (atelic non-dynamic) lexemes (Lehmann 1998: 295).11

11 Conversely, atelic decursive lexemes such as drijema-, 'nap' sjedi- 'sit', spava- 'sleep' are typically labelled verbs of state (Cr. glagoli stanja) in Croatian grammaticography. 
Diffuse lexemes have lexical meanings with underspecified telicity. Consequently, they have no firmly determined default situational shape. In other words, their meaning can refer to a single integral phase or to any of many phases of a verbal situation. In the former case, they have the situational shape of an event and in the latter, of a course (Lehmann 1999a: 228). As already stated in Section 2.2.2, context allows them to be realized as either telic (with the situational shape of an event) or atelic (with the situational shape of a course) (Lehmann 1998: 297).

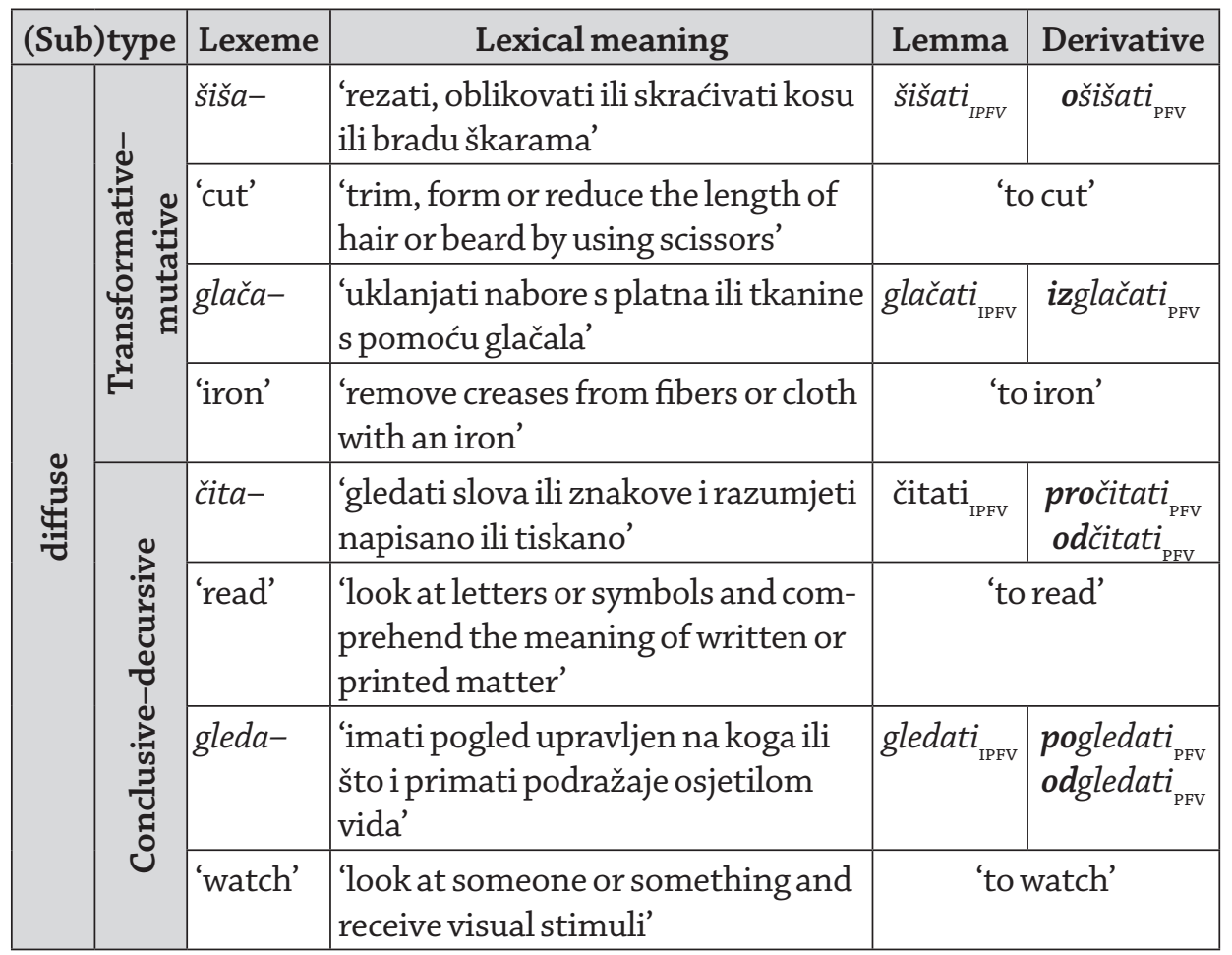

Table 5. Diffuse lexeme subtypes

As the examples presented in Table 5 suggest, the lexical meanings of diffuse transformative-mutative lexemes (e.g., šiša- 'cut' and glača- 'iron') imply a gradual change of a state of affairs. Unlike them, the meanings of some diffuse lexemes (e.g., čita- 'read' and gleda- 'watch') do not involve any change in a state of affairs (Lehmann 1998: 297). These lexemes are called conclusive-decursive in the formal-functional theory. It is important to emphasize that the diffuse lexeme type does not exist in Vendler's (1957) classification of actional properties (cf. Lehmann 1999a: 228). Such meanings are sometimes classified as activities and sometimes as accomplishments (cf. Vendler 1957).

Stative lexemes are atelic and their lexical meanings do not involve the notion of phase. This feature distinguishes them from atelic dynamic lexemes (Lehmann 
1998: 295). Their default functional shape is stative. They correspond to state verbs in Vendler's (1957) classification (cf. Lehmann 1999a: 228). As can be seen in Table 6 , stative verbal lexemes are also divided into two subclasses in the formal-functional theory of verbal aspect. Some of them allow the concept of entering into a state to be expressed (e.g., zna- 'know' and pripada- 'belong'), while others (e.g., znači- 'mean' and odgovara- 'suit') do not. The former are relative and the latter absolute stative lexemes.

\begin{tabular}{|c|c|c|c|c|c|}
\hline \multicolumn{2}{|c|}{ (Sub)type } & Lexeme & Lexical meaning & Lemma & Derivative \\
\hline \multirow{8}{*}{ 孪 } & \multirow{4}{*}{ 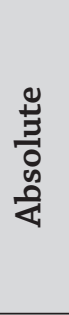 } & znači- & 'nositi, imati kakvo značenje' & značiti & - \\
\hline & & 'mean' & 'carry, have a meaning' & \multicolumn{2}{|c|}{ 'to mean' } \\
\hline & & $\begin{array}{l}\text { odgo- } \\
\text { vara- }\end{array}$ & $\begin{array}{l}\text { 'biti pogodan, prihvatljiv, dobar za } \\
\text { neku namjenu' }\end{array}$ & odgovarati & - \\
\hline & & 'suit' & $\begin{array}{l}\text { 'be acceptable or convenient for a } \\
\text { certain purpose' }\end{array}$ & \multicolumn{2}{|c|}{ 'to suit' } \\
\hline & \multirow{4}{*}{ 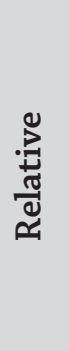 } & zna- & $\begin{array}{l}\text { 'biti upućen u što, imati znanje o } \\
\text { čemu' }\end{array}$ & znati & doznati \\
\hline & & 'know' & $\begin{array}{l}\text { 'be informed, have knowledge or } \\
\text { information concerning somet- } \\
\text { hing' }\end{array}$ & \multicolumn{2}{|c|}{ 'to know' } \\
\hline & & pripada- & 'biti čijim vlasništvom' & pripadati & pripasti \\
\hline & & 'belong' & 'be the property of' & \multicolumn{2}{|c|}{ 'to belong' } \\
\hline
\end{tabular}

Table 6. Stative lexeme subtypes

\subsection{Morphological level: default aspectual coding and derivation of aspectual partners}

\subsubsection{Default aspectual coding of telic lexemes and derivation of aspectual partners}

As stated in Section 2.2.3, telicity has serious implications for the default realization of situational shape: telic lexical meanings imply the situational shape of an event, whereas atelic meanings have either the situational shape of course (atelic dynamic) or of stative situation (stative). Moreover, Table 1 shows the impact of the lexical base with its lexical-actional function (telicity and situational shape) for the realization of (im)perfective aspectual value on the morphological, sentential and textual level. By default, telic lexemes (e.g., da- 'give', stavi- 'put', uključi- 'join' and zahvali- 'thank') are (usually) coded as perfective (e.g., dati 'give', staviti 'put', uključiti 'join' and zahvaliti 'thank') and ateliclexemes (e.g., plovi- 'sail', pliva- 'swim', drijema- 'nap', zvoni- 'ring', znači- 'mean' and odgovara- 'suit') as imperfective (e.g., ploviti 'sail', plivati 'swim', drijemati 'nap', zvoniti 'ring', značiti 'mean' and odgovarati 
'suit'). Nevertheless, this can be modified above the lexical level. This and the following subsections clarify exactly how this works.

At morphological and higher levels, telic meanings can attain the situational shape of a course. This means that aspectual (grammatical) derivation enables imperfective coding of telic lexemes (Lehmann 1999a: 224). Since the meanings of telic transformative lexemes (e.g., da- 'give' and stavi- 'put') are not incompatible with the semantic component of duration, above the lexical level these meanings can be reinterpreted as multiphase and hence used in progressive contexts (Lehmann 1998: 298). In such cases, instead of their default perfective forms (e.g., dati 'to give', staviti 'to put'), aspectual imperfective derivatives (e.g., davati 'to give', stavljati 'to put') are used. In contrast, the meanings of telic conclusive lexemes (e.g., zahvali- 'thank' and uključi- 'join') lack the semantic component of duration (Lehmann 1998: 298). Nevertheless, in certain contexts some of them can be reinterpreted as multiphase and hence used in progressive contexts (Lehmann 1998: 298f). For instance, due to the physical (concrete) component of the meaning of speech act verbs which is related to the phonetic or graphical realization of the speech act in question, such lexemes can take on the characteristics of a multiphase situation (Lehmann 1998: 298). Hence, an imperfective derivative which can denote a progressive situation can be formed (e.g., zahvaljivati 'to thank') out of the default perfective (e.g., zahvaliti 'to thank'). Similarly, in the case of mental act verbs progressivity is achieved by the semantic component 'approaching the inner boundary' or by the agentive component (Lehmann 1998: 299). To sum up: if a telic lexical meaning which by default has the situational shape of an event has to be used in a progressive situation, its default functional shape can be changed into a course via aspectual affixation.

\subsubsection{Default aspectual coding of atelic dynamic lexemes and derivation of aspectual partners}

As explained in the previous subsection, atelic dynamic meanings (e.g., plovi- 'sail', pliva- 'swim', drijema- 'nap', zvoni- 'ring') have the situational shape of a course by default. Furthermore, on the morphological level they are typically coded as imperfective (e.g., ploviti 'to sail', plivati 'to swim', drijemati 'to nap', zvoniti 'to ring'). Given that such meanings imply a multiphase structure, their beginning and end phase can easily be highlighted (cf. Lehmann 1999a: 218).12 If the beginning (e.g., zaploviti 'to sail', zaplivati 'to swim', zadrijemati 'to nap', zazvoniti 'to ring') or end phase (e.g., otploviti 'to sail', otplivati 'to swim', odrijemati 'to nap', odzvoniti 'to ring') is highlighted, the new situation consists of only one phase, has the situational shape of an event and is coded as perfective (Lehmann 1999a: 218; Lehmann

12 Unlike in Russian, in Croatian highlighting the middle phase with the prefix po- is limited only to some lexemes. 
2009a: 11f).13 To conclude, on the morphological level perfective coding of atelic lexemes is possible via aspectual (grammatical) derivation (Lehmann 1999a: 224).

\subsubsection{Default aspectual coding of diffuse dynamic lexemes and derivation of aspectual partners}

The previous section already reported that diffuse lexemes (e.g., šiša- 'cut', glača- 'iron', čita- 'read', gleda- 'watch') have underspecified telicity and consequently also underspecified situational shape. Furthermore, on the morphological level they are typically coded as imperfective (e.g., šišati 'to cut', glačati 'to iron', citati 'to read', gledati 'to watch'). On the morphological level perfective coding of diffuse lexemes is possible via aspectual (grammatical) prefixation (Lehmann 2009a: 25). First, perfective coding of diffuse lexemes can happen via prefixation with various prefixes usually called "empty prefixes" (e.g., ošišati 'to cut', izglačati 'to iron', pročitati 'to read', pogledati 'to watch'). Secondly, given that such meanings can imply multiphase structure, their beginning and end phases can easily be highlighted, just like in the case of atelic dynamic lexemes (cf. Lehmann 1999a: 218). In other words, perfective coding of diffuse lexemes can also be done through prefixation with the prefixes za- (e.g., zapjevati 'to sing', zaplesati 'to dance'), po-(e.g., poplesati 'to dance'; in Croatian this prefix is used only to a limited extent in a delimitative function) and od-(e.g., odčitati 'to read', odgledati 'to watch'). In either case, the new situation consists of only one phase, has the situational shape of an event and is coded as perfective. In the former case the lexemes are telic and in the latter, atelic (cf. Lehmann 2009a: 26).

\subsubsection{Default aspectual coding of stative lexemes and derivation of aspectual partners}

As already mentioned in the previous section, stative lexemes are atelic and their lexical meanings do not involve the notion of phase (e.g., znači- 'mean', odgovara- 'suit'). Furthermore, they are coded as imperfective (e.g., značiti 'mean', odgovarati 'suit') on the morphological level by default. In the case of absolute stative lexemes these features remain stable on all the described language levels (Lehmann 2009a: 12). In other words, the absence of a phasal structure blocks derivation of aspectual partners of absolute stative lexemes with an atelic stative function on the morphological and higher levels (Lehmann 1993: 277; Lehmann 1999a: 226; Lehmann 2009a: 8). In contrast, relative stative lexemes (e.g., zna- 'know', pripa$d a-$ 'belong') allow the functional equivalence of perfective derivative (i.e., doznati 'know', pripasti 'belong') and the imperfective base verb (i.e., znati 'know', pripadati 'belong'). In other words, relative stative lexemes can have syntactic aspectual partners, while absolute ones cannot (Lehmann 2009a: 18).

13 If the middle phase is highlighted (which is rather rare in Croatian as compared to Russian), it is not clear exactly which one in a series of middle phases it is. Therefore, the new situation is still perceived as a course (Lehmann 1999a: 218). 


\subsubsection{Interplay between the lexical and the morphological level: actionality and morphology}

The formal-functional theory recognizes the importance of the lexical base and accordingly of actional features. The actional properties of the lexical base influence not only the default aspect coding on the morphological level, but also whether the same lexical meaning can be realized in the opposing aspectual value by means of aspectual derivation. Moreover, actional properties of the lexical base affect the type of aspectual affixation.

As a rule, the aspectual partners of telic lexemes are derived by suffixation, while the aspectual partners of atelic dynamic and stative and of diffuse lexemes are formed by prefixation. Furthermore, in the case of the latter two types, actional properties also have an impact on prefix choice. Perfective aspectual partners of atelic dynamic lexemes are usually formed with the prefixes za- (e.g., zaplivati 'to swim', zadrijemati 'to nap') and od- (e.g., otplivati 'to swim', odrijemati 'to nap'),14 and perfective aspectual partners of relative stative lexemes are often formed with the prefix za- (e.g., zavoljeti 'to love', zamrziti 'to hate') (cf. Breu 1980: 208-209; Lehmann 2009a: 26). In contrast, perfective aspectual partners of diffuse lexemes are usually formed with various prefixes which are called "empty prefixes" in traditional aspectology (e.g., ošišati 'to cut', izglačati 'to iron', pročitati 'to read', pogledati 'to watch') (cf. Lehmann 2009a: 26-27). Nevertheless, due to their underspecified telicity some diffuse lexemes can form perfective aspectual partners with prefixes which are typically used with atelic lexemes, such as za- (e.g., zapjevati 'to sing', zaplesati 'to dance') and od- (e.g., otpjevati 'to sing', otplesati 'to dance', odčitati 'to read', odgledati 'to watch').

\section{Causes of (un)stable biaspectuality: literature overview}

\subsection{Actionality and biaspectuality}

Various factors influencing biaspectuality are cited in the literature, including semantics and the actional properties of the base BV (cf. Mučnik 1966: 68; Avilova 1968: 66; Šeljakin 1983: 149). Moreover, it seems that only verbs with certain meanings develop biaspectuality (cf. Belić 1955-56: 7).

Since the second half of the last century, authors (e.g., Čertkova and Čang 1998; Janda 2011; Lehmann 2009a; Maslov 1963) have reported that telicity is the key feature enabling realization of biaspectuality or that is tightly related to it. Some (e.g., Janda 2007b; Janda 2011: 20; Lehmann 2009a: 31) argue that only telic verbs can be biaspectual. It has been pointed out that all Russian and Bulgarian verbal bases with the -ir-infix (e.g., diskutira- 'discuss', eksploatira- 'exploit', deklamira-

14 Perfective po-derivatives of atelic dynamic and diffuse lexemes (e.g., poplivati 'to swim', poplesati 'to dance') are extremely rare in Croatian. Unlike their Russian counterparts they do not mean 'for a while', but rather 'a little bit' and usually appear with malo 'little/bit' in a broader context. 
'declaim'), which are atelic, are imperfective only (Maslov 1963: 102f). Presumably, the absence of an internal boundary, i.e., the atelicity of these verbal bases, prevents the perfective aspectual value from emerging in them (cf. Maslov 1963:103).

Further, the role of telicity in biaspectuality has also been inferred from Bulgarian dictionary entries. As observed in the literature (e.g., Maslov 1963: 101), these are not uniform with respect to application of (bi)aspectual labels to certain verbs whose meanings (lexemes) denote the existence or long-term position of an entity in a particular place or its relationship with the habitat (e.g., dominira'dominate', simpatizira-, 'sympathize', figurira- 'figure'), and to certain verbs whose lexemes denote a professional or temporary occupation (e.g., agitira- 'agitate' and administrira- 'administer'). In most cases, Bulgarian dictionaries classify such verbs as imperfective. Their potential perfective meaning, and consequently their biaspectuality, are closely related to their transitive usage (cf. Maslov 1963: 101). Similarly, Bulgarian dictionaries exhibit some disagreement in (bi)aspectual labelling of verbs with the infix -ir-, whose meanings are atelic and intransitive (e.g., vegetira- 'vegetate', pozira- 'pose', datira- 'date' (the latter in the meaning 'originate at a particular time; have existed since'). Note that the Russian equivalents of the above-mentioned verbs are imperfective and have no perfective pairs (cf. Maslov 1963: 101f; Avilova 1968: 66).

As already mentioned, an interplay between telicity and biaspectuality is also reported for Russian. Nevertheless, one group of Russian biaspectual telic verbs can be prefixed, i.e., perfectivized (cf. Maslov 1963: 103f).

Finally, recent aspectological literature (e.g., Janda 2007b: 97-102; Janda 2011: 18, 20) corroborates that there is a strong relationship between biaspectuality and (a)telicity. Namely, there is a strong negative correlation between biaspectuality and atelic perfective derivatives formed with the prefixes po-, pro-, za- and to some extent those formed with the prefixes ot-, raz-, na-in Russian.

\subsection{Aspectual affixation of biaspectual verbs}

As already mentioned in Section 1, native speakers occasionally use aspectual affixation to derive overtly aspectually marked verbs from BVs. However, aspectologists' opinions on this differ. ${ }^{15}$ Some consider it to be the first step in the gradual and persistent incorporation of BVs into the Slavic binary aspectual system. In other words, they (e.g., Čertkova and Čang 1998; Jászay 1999; Zaliznjak \& Šmelëv 2000) believe that BVs with aspectual derivatives gradually become aspectually defined. Others (e.g., Anderson 2002; Chromý 2014: 88; Donchenko 1971; Ivančev 1971; Smiešková 1961; Veselý 2010), however, argue that there are examples of BVs which have not yet lost their biaspectual status despite having had (im)perfective correlates for an extended period of time.

15 As in other Slavic languages, also in Croatian aspectological literature there is a very controversial debate on whether prefixed derivatives should be considered aspectual partners, i.e., counterparts: see Kolaković (2020) for an overview. 
In addition, not all $\mathrm{BV}$ s are equally prone to (aspectual) affixation. For instance, it has been claimed that in Russian less than $1 / 3$ of all BVs form aspectual derivatives (cf. Mučnik 1966: 65). Moreover, restrictions on aspectual affixation of BVs in Russian may principally be caused by semantics, but it has been suggested in the literature that stress and morphological restrictions might also play an important role (e.g., Mučnik 1966: 65). This said, in Russian telic BVs seem to be the most probable candidates for aspectual affixation (cf. Avilova 1968: 66; Šeljakin 1983: 149). However, to my best knowledge these assertions have not been tested empirically. Still, they seem quite plausible, above all given the well-known general and partially empirically tested aspectological fact that the type of aspectual affixation and inner actional properties of a verb are highly interrelated (cf. Breu 1980, 1985, 1994; Janda 2007a, 2011, 2012b; Lehmann 1999a, 2009a, 2009b).16

\subsection{Null-hypothesis}

Before presenting the research hypothesis, I will recapitulate the most important facts on BVs presented in this paper. BVs differ with respect to their biaspectuality: some are closer to the PFV, and others to the IPFV pole (see Section 1). On the one hand, telicity appears to be an essential semantic feature closely associated with the emergence of biaspectuality (see Section 3.1). On the other hand, telicity also emerges as a key trait enabling aspectual affixation of BVs (see Section 3.2). However, to my best knowledge, there is still a lack of empirical studies on this matter. Therefore, I propose the following null-hypothesis:

\section{$\mathrm{H}_{0.1} \quad$ There is no difference in the lexical-actional functions (actional pro- perties) of BVs which do and those which do not undergo different types of aspectual affixation.}

In other words, in the null-hypothesis I assume that lexical-actional functions (actional properties) of those BVs which do and those which do not form overtly aspectually marked derivatives do not differ significantly.

\section{Data: samples, sources and annotation process}

\subsection{Population and samples of biaspectual verbs}

According to the list contained in the doctoral dissertation Dvovidniglagoli u hrvatskome i slovenskome jeziku (Smailagić 2011), there are more than a thousand BVs in Croatian. However, no precise information about the number of BVs in Croatian can be found in the study. Further, it becomes apparent from the list that dictionaries provide contradictory information on the (bi)aspectual values of some lemmas.

16 For empirical studies of various factors on the morphological and syntactic levels contributing to prefixation of BVs, consult Kolaković (2018), Kolaković (2021), Kolaković (forthcoming a, b). 
Aspectological literature reports this as a general problem (e.g., Chromý 2014: 89; Čertkova and Čang 1998: 24f; Ivančev 1971: 175; Janda 2007b: 14; Jászay 1999: 169; Kopečný1962: 42; Maslov 1963: 96f).

In any case, it can be stated that Croatian BVs form several distinct groups with respect to morphological structure: 17

1) BVs of Slavic origin belonging to various conjugation types (closed group), e.g., savjetovati 'to advise', noćiti 'to spend the night', večerati 'to have dinner', veljeti 'to say'

2) biaspectual borrowings with the -irati suffix (the largest group), e.g., ilustrirati 'to illustrate', intervenirati 'to intervene'

3) biaspectual borrowings with the -isati and -ovati suffixes, (non-standard variants of BVs with the -irati suffix), e.g., ilustrovati 'to illustrate', intervenisati 'to intervene'.

4) biaspectual borrowings belonging to various conjugation types, many of which are regionally restricted or used exclusively in the colloquial register e.g., vrbovati 'to recruit', sejvati 'to save', divertiti 'to amuse'

5) biaspectual borrowings with the -isati suffix, regionally restricted (without-irati variants), e.g., begenisati 'to approve', saulisati 'to control oneself'

Only verbs from groups 1 and 2 are analyzed in this study. To empirically test the null-hypothesis, first two stratified random samples ${ }^{18}$ of BVs were drawn from the list in Smailagić (2011). The smaller sample contained BVs of Slavic origin (37 verbs) and the larger sample consisted of biaspectual verbal borrowings (200 verbs) with the -irati suffix. For both samples, only lemmas which were labelled as biaspectual in both Jojić et al. (2015) and Matasović and Jojić (2002) were included in the subsamples. In the second step, data on (aspectual) affixation of those 237 verbs were extracted from three corpora and one subcorpus of contemporary Croatian language. These were: hrWaC and its subcorpus Forum (Ljubešić and Klubička 2014), the Croatian National Corpus (Tadić 1998, 2002) and the Croatian Language Repository (Ćavar and Brozović Rončević 2012).19, 20 Next, BVs from these

17 Smailagić (2011) does not actually divide the BVs on his list into these five groups, nor does he give exact counts of how many BVs from the list are colloquial or regionally restricted; he merely lists verbs with their assigned aspectual value according to Slovar slovenskega knjižnega jezika (Bajec et al. 1994), Slovenski pravopis (Toporišič 2001), Rječnikhrvatskogajezika (Šonje and Nakić 2000), Hrvatski enciklopedijski rječnik (Matasović and Jojić 2002) and Veliki rječnik hrvatskoga jezika (Anić 2003).

18 For more information on sampling and types of samples see Buchstaller and Khattab (2013).

19 The Croatian Language Repository is also known as the Riznica Croatian Language Corpus (https://www. clarin.si/noske/all.cgi/corp_info?corpname=riznica\&struct_attr_stats=1\&subcorpora=1).

20 The Croatian National Corpus (Tadić 1998, 2002) (CNC) and the Croatian Language Repository (Ćavar and Brozović-Rončević 2012) (Repository) are corpora of standard Croatian. In contrast, the hrWaC (Ljubešić and Klubička 2014) contains both standard Croatian (proofread language material) and colloquial Croatian (i.e., non-proofread) texts, while its subcorpus Forum is composed exclusively of user-generated non-edited content (without external proofreading). For more information on this and on the advantages of web corpora see Kolaković et al. (forthcoming), Jurkiewicz-Rohrbacher, Kolaković and Hansen (2017), Kolaković, Jurkiewicz-Rohrbacher and Hansen (2019: 511f) and references therein. 
two samples were divided into the following four groups according to derivational criteria:

1) BVs with only ${ }^{21}$ suffixed derivatives attested in hrWaC22 (PF0 SUF1), $\mathrm{N}=8$ (e.g., asocirati-asociravati 'to associate')

2) BVs with no attested derivatives in any of the examined corpora (PF0 SUF0), N=39 (e.g., apelirati 'to appeal to')

3) BVs with only prefixed derivatives attested in all examined corpora (PF1 SUF0), N=38 (e.g., karakterizirati 'to characterize')

4) BVs with both prefixed and suffixed derivatives, with the former attested in all examined corpora (PF1 SUF1), N=23 (e.g., častiti - počastiti, častiti čašćavati 'to pay for dinner/lunch/to honor').

The division of BVs into these four groups resulted in a reduction of the number of BVs $(\mathrm{N}=108)$. This was because only BVs with prefixed derivatives attested in all the examined corpora (groups PF1 SUF0 and PF1 SUF1), and BVs with no derivatives in any of the examined corpora (group PF0 SUF0) were taken into account.

These first results corroborate two assumptions from the aspectological literature. First, not all BVs are equally prone to (aspectual) affixation (in accordance with Mučnik 1966). Secondly, there are BVs which are closer to the imperfective pole (i.e., BVs from PF1 SUF0), and those more inclined to the perfective aspectual pole (i.e., BVs from PF0 SUF1). Still others fall in the middle of this biaspectuality continuum (i.e., BVs from PF0 SUF0) (in accordance with Isačenko 1960; Maslov 1984 and Piperski 2018).

\subsection{Subsamples for the purpose of this study and the annotation process}

In the last step, the lexical-actional functions (actional properties) of each lexeme (meaning) of the biaspectual lemmas from those four different groups had to be annotated. As verbs are extremely polysemous, the manual extraction of individual meanings of $108 \mathrm{BV}$ s and consequently the annotation of actional properties seems a topic for a long-term project. Therefore, it was necessary to form a new subsample for each of the four above-mentioned groups. Since the PF0 SUF1 group contained only eight eligible biaspectual lemmas (see previous subsection), it was decided that the maximum number of lemmas in the other three groups would not

21 The lemmas ručati 'to have lunch' and večerati 'to have dinner' are an exception to this. Specifically, their prefixed derivatives are attested in some, but not all examined corpora. However, they were included in this group for two reasons. First, as already stated their prefixed derivatives are not attested in all the examined corpora and in general their suffixed derivatives are much more frequent in the corpora. The second reason for including them in this group was of a practical nature - to enlarge the number of representatives in this group, which was important for statistical analysis.

22 Suffixed derivatives of some lemmas were attested in other examined corpora as well. Nevertheless, suffixed derivatives of BVs are generally extremely rare in the Croatian National Corpus. Therefore, unlike for prefixed derivatives, a strict criterion of "derivatives found in all inspected corpora" was not applicable here. 
exceed ten. Finally, random subsamples of BVs from the four groups were formed using the Excel function RAND, see Table 7.

\begin{tabular}{|c|c|c|c|c|}
\hline & PF1 SuF0 & PF1 SuF1 & PF0 SuF1 & PF0 SUF0 \\
\hline 1. & $\begin{array}{l}\text { aranžirati } \\
\text { 'to arrange' }\end{array}$ & $\begin{array}{l}\text { blokirati } \\
\text { 'to block' }\end{array}$ & $\begin{array}{l}\text { asocirati } \\
\text { 'to associate' }\end{array}$ & $\begin{array}{l}\text { apelirati } \\
\text { 'to appeal to' }\end{array}$ \\
\hline 2. & $\begin{array}{l}\text { blamirati } \\
\text { 'to embarrass' }\end{array}$ & $\begin{array}{l}\text { častiti } \\
\text { 'to pay for dinner/ } \\
\text { lunch/to honour' }\end{array}$ & $\begin{array}{l}\text { ekskomunicirati } \\
\text { 'to excommuni- } \\
\text { cate' }\end{array}$ & $\begin{array}{l}\text { apstrahirati } \\
\text { 'to abstract' }\end{array}$ \\
\hline 3. & $\begin{array}{l}\text { bombardirati } \\
\text { 'to bomb' }\end{array}$ & $\begin{array}{l}\text { definirati } \\
\text { 'to define' }\end{array}$ & $\begin{array}{l}\text { eksplodirati } \\
\text { 'to explode' }\end{array}$ & $\begin{array}{l}\text { dotirati } \\
\text { 'to donate/to pro- } \\
\text { vide financial help' }\end{array}$ \\
\hline 4. & $\begin{array}{l}\text { cirkulirati } \\
\text { 'to circulate' }\end{array}$ & $\begin{array}{l}\text { drogirati } \\
\text { 'to take stimu- } \\
\text { lants' }\end{array}$ & $\begin{array}{l}\text { impresionirati } \\
\text { 'to impress' }\end{array}$ & $\begin{array}{l}\text { evocirati } \\
\text { 'to evoke' }\end{array}$ \\
\hline 5. & $\begin{array}{l}\text { garantirati } \\
\text { 'to guarantee' }\end{array}$ & $\begin{array}{l}\text { jebati } \\
\text { 'to fuck' }\end{array}$ & $\begin{array}{l}\text { rezultirati } \\
\text { 'to result' }\end{array}$ & $\begin{array}{l}\text { galvanizirati } \\
\text { 'to galvanize' }\end{array}$ \\
\hline 6. & $\begin{array}{l}\text { karakterizirati } \\
\text { 'to characterize' }\end{array}$ & $\begin{array}{l}\text { informirati } \\
\text { 'to inform' }\end{array}$ & $\begin{array}{l}\text { ručati } \\
\text { 'to have lunch' }\end{array}$ & $\begin{array}{l}\text { ilustrirati } \\
\text { 'to illustrate' }\end{array}$ \\
\hline 7. & $\begin{array}{l}\text { licitirati } \\
\text { 'to bid' }\end{array}$ & $\begin{array}{l}\text { minirati } \\
\text { 'to mine' }\end{array}$ & $\begin{array}{l}\text { uzurpirati } \\
\text { 'to usurp' }\end{array}$ & $\begin{array}{l}\text { inscenirati } \\
\text { 'to stage' }\end{array}$ \\
\hline 8. & $\begin{array}{l}\text { normirati } \\
\text { 'to standardize' }\end{array}$ & $\begin{array}{l}\text { montirati } \\
\text { 'to put up/to in- } \\
\text { stall' }\end{array}$ & $\begin{array}{l}\text { večerati } \\
\text { 'to have dinner' }\end{array}$ & $\begin{array}{l}\text { intervenirati } \\
\text { 'to intervene' }\end{array}$ \\
\hline 9. & $\begin{array}{l}\text { savjetovati } \\
\text { 'to advise' }\end{array}$ & $\begin{array}{l}\text { nociiti } \\
\text { 'to spend the } \\
\text { night' }\end{array}$ & & $\begin{array}{l}\text { mumificirati } \\
\text { 'to mummify' }\end{array}$ \\
\hline 10. & $\begin{array}{l}\text { strukturirati } \\
\text { 'to structure' }\end{array}$ & $\begin{array}{l}\text { okupirati } \\
\text { 'to occupy' }\end{array}$ & & $\begin{array}{l}\text { veljeti } \\
\text { 'to say' }\end{array}$ \\
\hline
\end{tabular}

Table 7. Subsamples of morphologically stable and unstable biaspectual verbs

For each biaspectual lemma presented in Table 7, all the meanings contained in Matasović and Jojić (2002) were extracted in an Excel table. As a complementary source of information on lexical meanings Jojić et al. (2015) and Birtić et al. (2013) were used. The latter was used only partially since it does not contain all the analyzed verbs. Moreover, it is important to note that meaning variants were listed as separate meanings (lexemes) in the Excel table (i.e., as lexeme ${ }_{1}^{-}$, lexeme $_{2}-$, $_{\text {lexeme }}-$ 
etc.), see Figure 1. First, because in some cases they have different actional properties. Secondly, as this approach is better for statistical analysis. ${ }^{23}$

In the next step, all the listed meanings (lexemes) of each lemma were classified according to their actional class (i.e., telic, atelic dynamic...) and their LAF (i.e., conclusive, transformative, decursive...). For an illustration of the annotation scheme see Figure 1.

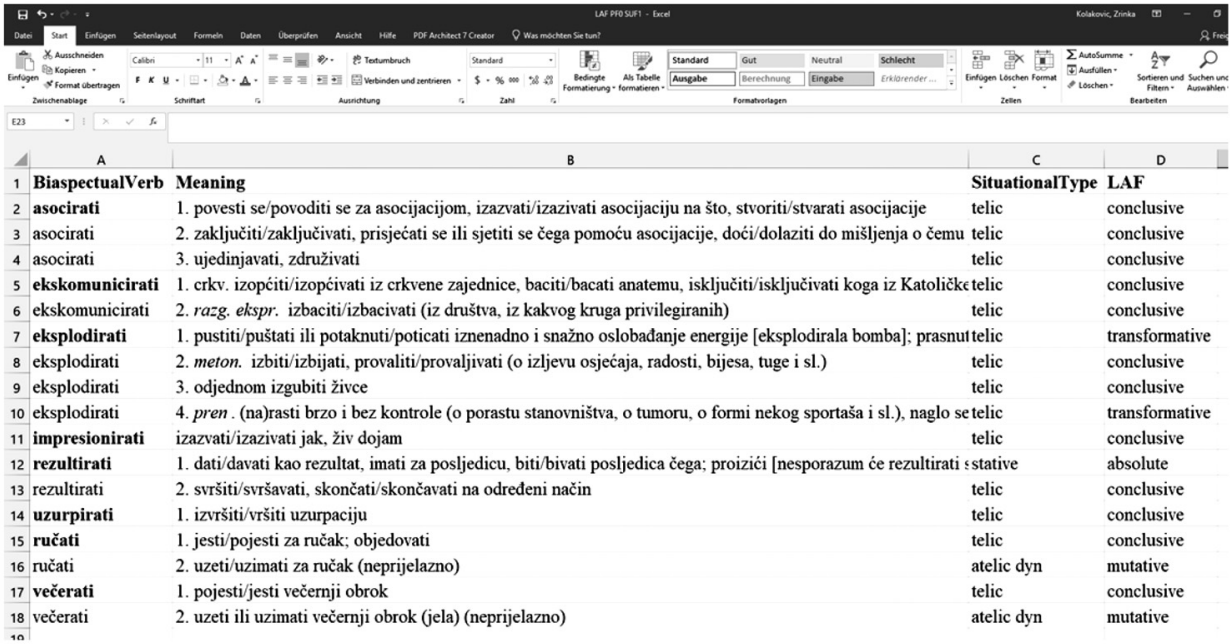

Figure 1. Annotation of actional features of biaspectual verbs from group PF0 SUF1

\section{Results and implications}

\subsection{Results and discussion}

Figure 2 shows the distribution of dependent (type of aspectual affixation) and independent (LAF) variables. The dependent variable has four levels: no aspectual affixation (PF0 SUF0), aspectual suffixation (PF0 SUF1), aspectual prefixation (PF1 SUF0), both types of aspectual affixation - prefixation and suffixation (PF1 SUF1). By contrast, the independent variable has six levels: conclusive (conclus), transformative (transform), decursive (decurs), mutative (mut), absolute stative (abs), relative stative (rel) LAF.

23 Based on her many years of empirical research experience in the field of semantics, Associate Professor D. Filipović Đurđević (p.c.) advised that for statistical analysis it is better to count variants of meaning as special meanings. 


\section{BiaspectualType}

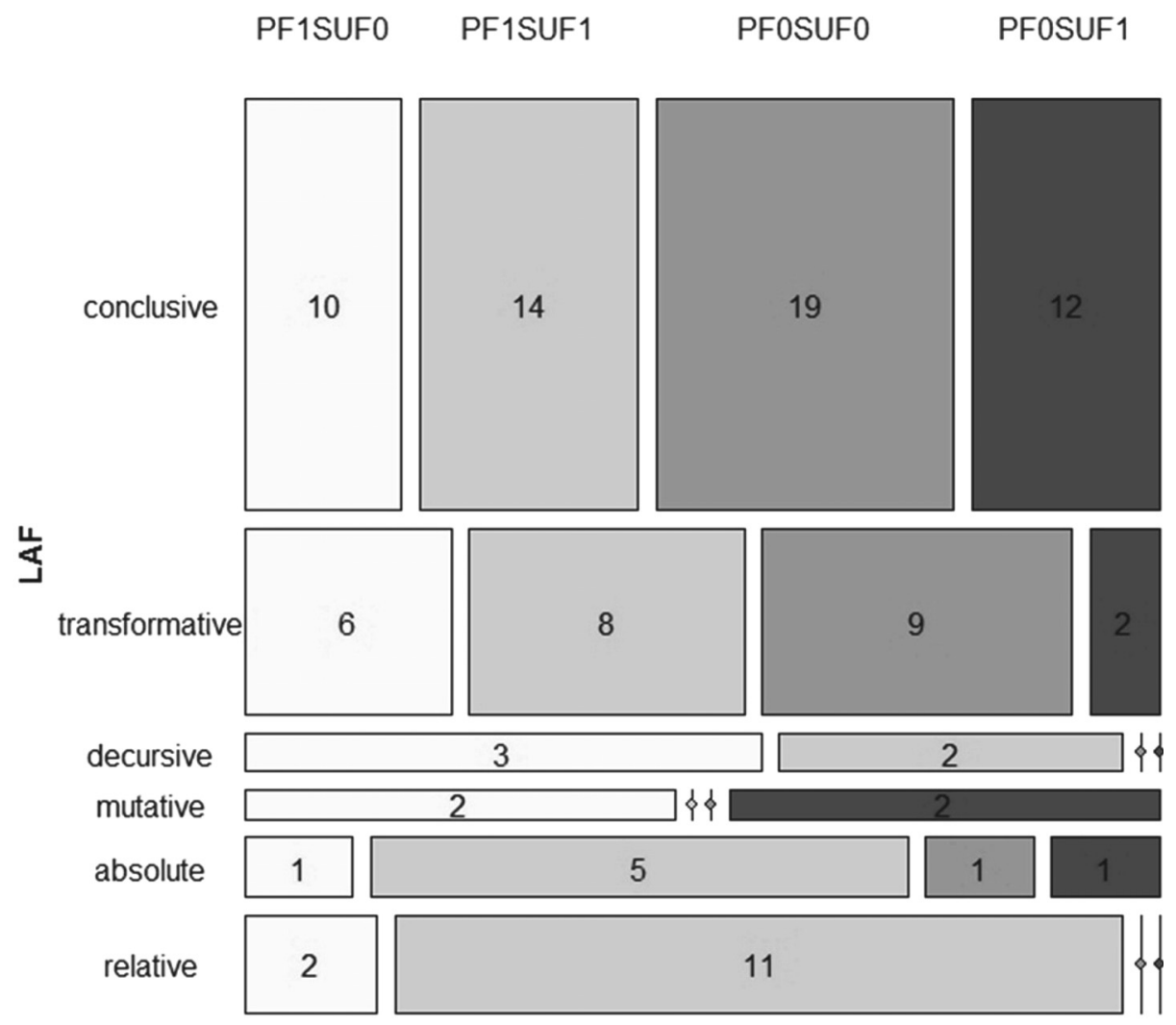

Figure 2. Aspectual affixation and actional properties (LAFs) across different types of (un)stable BVs

At first glance the observation emerges that LAFs of morphologically unstable BVs differ somewhat from LAFs ascribed to meanings of stable BVs. In the following lines the results will be presented in the form of some general observations. Atelic dynamic and stative meanings will be examined more closely, since these meanings are usually associated only with the imperfective aspectual value.

BVs with no aspectual affixation almost exclusively (with one exception) have telic meanings: 19 meanings have conclusive and 9 have transformative LAFs. Only the lemma ilustrirati in its meaning 'to be an example, to serve as an example/explanation' has an absolute stative LAF.

BVs with suffixed derivatives also predominantly have telic meanings: 12 meanings have conclusive and two have transformative LAFs. Two meanings are atelic dynamic and have mutative LAFs. Also in this group there is only one lemma with an absolute stative LAF: rezultirati in the meaning 'to have as an outcome/be an outcome'. 
Telic meanings also prevail in the group of BVs with prefixed derivatives. Nevertheless, atelic meanings are more numerous in this group than in the first two. Ten meanings have conclusive and six have transformative LAFs. By contrast, five meanings are atelic dynamic. Decursive LAFs are observed in two lemmas and three meanings: bombardirati 'to trouble or annoy (someone) with something frequent or persistent (like questions or suggestions)', licitirati ' 'to emphasize something as valuable, show off one's efforts' and licitirati ${ }_{2}$ 'to bid'.24 A mutative LAF is noted for both meanings of the lemma cirkulirati 'to circulate'. Further, the lemma garantirati 'to guarantee' has a relative stative LAF in both its meanings. Finally, one lemma, karakterizirati in its meaning 'to be a typical or characteristic representative of something', has an absolute stative LAF.

The morphologically most unstable group, BVs that form both prefixed and suffixed derivatives, has the greatest number of atelic meanings among the four groups of BVs. Nevertheless, telic meanings prevail also in this group: 14 meanings have conclusive and eight have transformative LAFs. The following observations can be made with respect to atelic meanings. Three lemmas (five meanings in total) have absolute stative LAF: častiti 'regard with great respect', drogirati se 'to be an addict', jebati se 'to be in a sexual relationship', jebati 'not to pay attention/to completely ignore', jebati 'to disrespect/despise'. A relative stative LAF is observed in 11 meanings: in both meanings of the lemma okupirati 'to occupy' and in the majority of meanings of the lemma blokirati 'to block'. Additionally, a decursive atelic dynamic LAF is observed with two meanings. In contrast, mutative atelic dynamic LAFs are not observed in the meanings of BVs from this group.

The presented qualitative analysis gives a glimpse of some differences in LAFs across four different groups of BVs. In an effort to establish whether these differences were due to chance, a quantitative analysis was carried out. In order to test the null-hypothesis presented in Section 3.3 the Fisher exact test was conducted in $\mathrm{R}$ ( $\mathrm{R}$ Core Team 2016). ${ }^{25}$ The computed $p$-value $=0.001119$ is significant and indicates that the null-hypothesis should be rejected.26, 27 Instead, for the time being an alternative hypothesis should be put forward: BVs which undergo differ-

24 It seems that the meaning of the English lemma 'bid' 'offer (a certain price) for something, especially at an auction' would best be classified as a conclusive telic lexeme (cf. https://www.lexico.com/definition/bid). However, its Croatian counterpart is explained as 'nadmetati se na dražbi' 'to vie in an auction' and therefore classified as a decursive atelic dynamic lexeme.

25 Fisher's exact test is an alternative to the $\chi 2$ test, which calculates the probability of error directly by adding up the probability of the observed distribution and all distributions that deviate from the null hypothesis further in the same direction (Stefanowitsch 2020: 228).

26 "[T] he probability that we are wrong in rejecting the null hypothesis is always the probability of the observed result plus the probabilities of all results that deviate from the null hypothesis even further in the direction of the observed frequency. This is called the probability of error (or simply p-value) in statistics" (Stefanowitsch 2020: 173).

27 "By convention, probability of error of 0.05 (five percent) is considered to be the limit as far as acceptable risks are concerned in statistics - if $\mathrm{p}<0.05$ (i.e., if $\mathrm{p}$ is smaller than five percent), the result is said to be statistically significant (i.e., not due to chance), if it is larger, the result is said to be non-significant (i.e., likely due to chance)" (Stefanowitsch 2020: 174). 
ent types of aspectual affixation differ in their lexical-actional functions. In other words, the way in which BVs form overtly aspectually marked derivatives or whether they do not form such derivatives at all is linked to their lexical meanings. More precisely, this is associated with the LAFs (actional properties) coded in their lexical meanings. This indicates that aspectual affixation of BVs is at least partially a functionally motivated process.

These results are in accordance with previous assumptions on the importance of telicity for BVs presented mainly in theoretical aspectological works concerning Russian (e.g., Avilova 1968; Čertkova and Čang 1998; Janda 2007b, 2011; Lehmann 2009a; Maslov 1963; Mučnik 1966; Šeljakin 1983). However, this is the first study to deliver empirical evidence on this issue in Croatian. Furthermore, as the empirical data suggest, not only is the formation of overtly aspectually marked derivatives of BVs connected to their LAFs: the morphological stability of BVs, i.e., their inability to undergo aspectual affixation, also depends on their actional properties. In the case in question, the BVs that are the most robust at the morphological level (as neither PFV nor IPFV derivatives from them are attested) have, almost without exception, only telic conclusive and transformative LAFs. By way of comparison, the meanings of BVs which show signs of unstable biaspectuality at the morphological level (i.e., are prone to form overtly aspectually marked PFV and IPFV derivatives) more greatly tend to have meanings with atelic LAFs. To conclude, the affixation of BVs cannot be considered an arbitrary process.

\subsection{Lexicographic problems of biaspectual labels}

Another interesting finding emerged during analysis of the actional properties of BVs. Namely, some BVs from the samples analyzed have meanings which are clearly not biaspectual. In the Croatian lexicographic tradition, verbal aspect is determined at lemma level. That is, one single aspectual value, either (I)PFV or biaspectual, is assigned to all meanings of a polysemous verb. However, many cases have been observed in which meanings of a single polysemous BV should be assigned different aspectual values. In other words, in some cases not all meanings should by definition have the same aspectual value. In the case in question, some verbs which are classified as biaspectual in Croatian dictionaries have meanings with absolute or relative stative LAFs.

Verbs with stative meanings, such as značiti 'to mean' and posjedovati 'to possess', are traditionally classified as IPFV at lemma level, which is perfectly correct. Having this in mind, it is rather problematic when the absolute stative meaning of a verb such as 'to be a typical or characteristic representative of something' (Birtić et al. 2013: 233; Jojić et al. 2015: 534; Matasović and Jojić 2002: 555) is subsumed under the biaspectual label of the whole lemma karakterizirati. This particular absolute stative meaning categorically cannot be expressed with the PFV aspect. It can only be conveyed with the IPFV aspect. Hence, it is not biaspectual, but IPFV only. At least in cases where the aspect of a specific meaning differs from the aspect 
of the lemma as a whole, dictionaries should indicate aspectual value at the level of a particular meaning. In comparison to Matasović and Jojić (2002) and Jojić et al. (2015), Birtić et al. (2013) signal divergent aspectual values at least to some degree. For example, Birtić et al. (2013) indicate that some meanings of lemmas drogirati (se) 'to take stimulants' and kopirati 'to copy' are imperfective. Nevertheless, this is not always consistently done for all meanings whose aspectual values diverge from the aspectual values ascribed to their lemmas.

\section{Conclusions}

Theoretical aspectological literature on other Slavic languages suggests that actionality in general and telicity in particular are features with a high significance for biaspectuality. In the present study the null-hypothesis on the difference between LAFs of BVs with and without overtly marked aspectual derivatives was verified on empirical data by means of the Fisher exact test. The results of the statistical test revealed a significant $p$-value (0.001119). This means that the differences between LAFs of BVs with and without overtly marked aspectual derivatives are very probably not due to chance. In other words, these results suggest that aspectual affixation and actionality of BVs are somehow interrelated. These results corroborate ideas from theoretical aspectological literature on other Slavic languages (e.g., Čertkova and Čang 1998; Lehmann 2009a; Janda 2011; Maslov 1963). Furthermore, the empirical study of BVs and their actionality also suggests that telicity is related to the morphological stability and preservation of biaspectuality. Specifically, the meanings of the analyzed BVs without attested overtly marked aspectual derivatives have, almost without exception, telic conclusive and telic transformative LAFs. Conversely, BVs with overtly marked aspectual derivatives have many more meanings with atelic LAFs (see Figure 2).

Although this paper brings the first empirical proof of the importance of actionality for the aspectual affixation of BVs, it should be emphasized that the results were obtained on a sample of only 38 BVs. Since BVs form a substantial group in Croatian, it would certainly be necessary to expand the database. It would be compelling to compare the LAFs of a larger number of verbs: possibly not only biaspectual verbs, but also IPFV and PFV verbs. As verbs are extremely polysemous, this could in fact be a subject for a future long-term project.

Finally, this paper draws attention to yet another practical lexicographic problem noticed during annotation, data processing and analysis. Namely, the presence of verbs such as karakterizirati 'to characterize', which are labeled biaspectual at the lemma level in Croatian dictionaries, although at least some of their meanings have absolute stative atelic LAFs. In such cases it would be good for aspect to be determined at the level of a particular meaning. If not, it would be advisable to at least provide comments on the aspectual value of those meanings which diverge from the aspectual values ascribed to the lemma as a whole. This solution has been partially applied in Birtić et al. (2013), but not always consistently enough. 


\section{References}

Anderson, Cori (2002). Biaspectual verbs in Russian and their implications on the category of aspect. Honor thesis. Chapel Hill: University of North Carolina-Chapel Hill, http:// www.academia.edu/292389/Biaspectual_Verbs_In_Russian_and_Their_Implications_on_the_Category_of_Aspect (accessed on August 8th 2020)

Anić, Vladimir (2003). Veliki rječnik hrvatskoga jezika. Zagreb: Novi liber

Apresjan, Jurij Derenikovič(1995a). Izbrannyetrudy 1:Leksičeskajasemantika: sinonimičeskie sredstva jazyka. Moskva: Škola Jazyki russkoj kul’tury

Apresjan, Jurij Derenikovič (1995b). Izbrannye trudy 2: Integral'noe opisanie jazyka i sistemnaja leksikografija. Moskva: Škola Jazyki russkoj kul'tury

Avilova, Natal'ja Sergeevna (1968). Dvuvidovye glagoly s zaimstvovannoj osnovoj v sovremennom russkom jazyke. Voprosy jazykoznanija 5: 66-78

Bajec, Anton, Janko Jurančič, Mile Klopčič, Lino Legiša, Stane Suhadolnik, France Tomšič, Bojan Čop, Jakob Rigler, Ivanka Černelič, Milena Hajnšek-Holz, Franc Jakopin, Zvonka Leder-Mancini, Tine Logar, Jakob Müller, Marjeta Humar, and Ivanka ŠirceljŽnidaršič (1994). Slovar slovenskega knjižnega jezika. Ljubljana: Slovenska akademija znanosti in umetnosti

Belić, Aleksandar (1955-56). O glagolima sa dva vida. Južnoslavenski filolog 21: 1-13

Berger, Tilman (2011). Perfektivierung durch Präfix im Tschechischen, vermeintliche und tatsächliche Besonderheiten. Wiener Slawistischer Almanach 67: 33-52

Birtić, Matea, Goranka Blagus Bartolec, Lana Hudeček, Ljiljana Jojić, Barbara Kovačević, Kristian Lewis, Ivana Matas Ivanković, Milica Mihaljević, Irena Miloš, Ermina Ramadanović, and Domagoj Vidović (2013). Školski rječnik hrvatskoga jezika. Zagreb: Školska knjiga

Breu, Walter (1980). Semantische Untersuchungen zum Verbalaspektim Russischen. München: Verlag Otto Sagner

Breu, Walter (1985). Handlungsgrenzen als Grundlage der Verbklassifikation. Lehfeldt, Werner, ed. Slavistische Linguistik 1984. München: Otto Sagner, 9-34

Breu, Walter (1994). Interactions between Lexical, Temporal and Aspectual Meanings. Studies in Language 18(1): 23-44

Buchstaller, Isabelle, and Ghada Khattab (2013). Population samples. Podesva, Robert J., and Devyani Sharma, eds. Research Methods in Linguistics. Cambridge: Cambridge University Press, 74-95

Car, Marko (1934). Antologija ružnoga. Naš jezik 2: 9-12

Chromý, Jan (2014). Impact of Tense on the Interpretation of Bi-Aspectual Verbs in Czech. Studie $z$ aplikované lingvistiky 2: 87-97

Čertkova, Marina Jurevna (1996). Grammatičeskaja kategorija vida v sovremennom russkom jazyke. Moskva: Izdatel'stvo Moskovskogo universiteta

Čertkova, Marina Jurevna, and Pej-Či Čang (1998). Ėvoljucija dvuvidovyh glagolovv sovremennom russkom jazyke. Russian Linguistics 22: 13-34

Ćavar, Damir, and Dunja Brozović Rončević (2012). Riznica: The Croatian Language Corpus. Prace filologiczne 63: 51-65 
Dickey, Stephen M. (2012). Orphan prefixes and the grammaticalization of aspect in South Slavic. Jezikoslovlje 13(1): 71-105

Donchenko, Adele Koskosky (1971). Biaspectual -ovat' verbs in Russian. University of Minnesota. Ph.D. Michigan: University Microfilms. A XEROX Company

Gehrke, Berit (2002). Aspectual affixes in Russian and Czech. MA Thesis. Berlin: Institut für Slavistik, Humboldt Universität

Gladney, Frank Y. (1982). Biaspectual Verbs and the Syntax of Aspect in Russian. The Slavic and East European Journal 26(2): 202-215

Horecký, Ján (1957). O tvorení slovies predponami. Slovenská reč 22(3): 141-155

Isačenko, Aleksandr Vasiljevič (1960). Grammatičeskij stroj russkogo jazyka v sopostavlenii s slovackim. Čast' vtoraja: morfologija. Bratislava: Izdatel'stvo Slovackoj akademii nauk

Ivančev, Svetomir (1971). Problemi na aspektualnostta v slavjanskite ezici. Sofia: Izdalestvo na Bâlgarskata akademija na naukite

Ivanova, Kalina (1964). Kăm văprosa za prefiksacijata na dvuvidovite glagoli ot čužd proizhod v săvremennija bălgarski ezik. Andrejčin, Ljubomir, Vladimir, Georgijev, Kiril Mirčev and Stojko Stojkov, eds. Izvestija na Instituta za bălgarski ezik11. Sofija: Izdatelstvo na Bălgarskata akademija na naukite, 245-251

Janda, Laura Alexis (2007a). Aspectual clusters of Russian verbs. Studies in Language 31(3): 607-648

Janda, Laura Alexis (2007b). What makes Russian Bi-aspectual verbs Special. Divjak, Dagmar and Agata Kochanska, eds. Cognitive Paths into the Slavic Domain. Berlin: Mouton de Gruyter, 83-109

Janda, Laura Alexis (2011). Completability and Russian aspect. Grygiel, Marcin and Laura Alexis Janda, eds. Slavic Linguistics in a Cognitive Framework. Vienna: Peter Lang, 13-35

Janda, Laura Alexis (2012b). Russkie pristavki kak sistema glagol'nyh klassifikatorov. Voprosyjazykoznanija $6: 3-48$

Janik, Christina (2008). Zur Chronologie, Episodizität, Deflexion und Kontinuität. Hodel, Robert, and Volkmar Lehmann, eds. Textkohärenz und Narration: Untersuchungen russischer Texte des Realismus und der Moderne. Berlin: Mouton de Gruyter, 275-306

Jászay, László (1999). Vidovye korreljaty pri dvuvidovyh glagolah. Studia Russica 17:169-177 Jojić, Ljiljana, Anuška Nakić, Nada Vajs Vinja, and Vesna Zečević (eds.) (2015). Veliki rječnik hrvatskoga standardnogjezika. Zagreb: Školska knjiga

Jurkiewicz-Rohrbacher, Edyta, Zrinka Kolaković, and Björn Hansen (2017). Web Corpora - the best possible solution for tracking rare phenomena in underresourced languages: clitics in Bosnian, Croatian and Serbian. Bański, Piotr, Marc Kupietz, Harald Lüngen, Paul Rayson, Hanno Biber, Evelyn Breiteneder, Simon Clematide, John Mariani, Mark Stevenson, and Theresa Sick, eds. Proceedings of the Workshop on Challenges in the Management of Large Corpora and Big Data and Natural Language Processing (CMLC$5+B i g N L P) 2017$ including the papers from the Web-as-Corpus (WAC-XI) guest section. Mannheim: Institut für Deutsche Sprache, 49-55

Kolaković, Zrinka (2018). Dvoaspektni glagoli - razlike između (p)opisa u priručnicama i stanja u korpusu s posebnim osvrtom na uporabu izvornih govornika. PhD Thesis. Regensburg/ Zagreb: Sveučilište u Regensburgu/Filozofski fakultet. Sveučilište u Zagrebu 
Kolaković, Zrinka (2020). Par - nepar - aspektni par. Jezikoslovlje 21(2): 103-147

Kolaković, Zrinka (2021). Factors contributing to prefixation of biaspectual verbs in Croatian. Russian Linguistics 45(2): 201-225. https://doi.org/10.1007/s11185-021-09244-3

Kolaković, Zrinka (forthcoming a). Aspectual sentential functions and affixation of biaspectual verbs. Zeitschrift für Slavische Philologie

Kolaković, Zrinka (forthcoming b). Glagolski vid i dvoaspektni glagoli u hrvatskome jeziku:formalno-funkcionalni pristup. Zagreb: Institut za hrvatski jezik i jezikoslovlje

Kolaković, Zrinka, Edyta Jurkiewicz-Rohrbacher, and Björn Hansen (2019). CC, the raising control dichotomy and diaphasic variation in Croatian - A corpus-based study. Rasprave: Časopis Instituta za hrvatski jeziki jezikoslovlje 45(2): 505-522. https://doi.org/10.31724/rihjj.45.2.13

Kolaković, Zrinka, Edyta Jurkiewicz-Rohrbacher, Björn Hansen, Dušica FilipovićĐurđević, and Nataša Fritz (forthcoming). Clitics in the Wild: Empirical Studies on the Microvariation of the Pronominal, Reflexive and Verbal Clitics in Bosnian, Croatian and Serbian. Berlin: Open Slavic Linguistics Series, Language Science Press

Kopečný, František (1962). Slovesný vid v češtině. Praha: Nakladatelství Československé akademie věd

Korošec, Tomo (1972). Nekateri slovenski nedovršni glagoli v dovršni funkciji. Seminar slovenskega jezika, literature in kulture 8, 202-215

Kravar, Miroslav (1980). Neke suvremene dileme oko glagolskoga vida (na građi hrvatskosrpskoga jezika). Radić, Radoje, ed. Jugoslavenski seminar za strane slaviste 31. Beograd: Štampa Minerva Subotica, 5-17

Lazić, Margarita (1976). Prefixation of Borrowed Verbs in Serbocroatian. The Slavic and East European Journal 20(1): 50-59

Lehmann, Volkmar (1992a). Grammatische Zeitkonzepte und ihre Erklärung. Kognitionswissenschaft 2: 156-170,

http://www.subdomain.verb.slav-verb.org/resources/VL.Zeitkonzepte.1992.pdf (accessed on March 12th 2020)

Lehmann, Volkmar (1993). Die russischen Aspekte als gestufte Kategorien: Ein Beispiel für die Bedeutung der kognitiven Linguistik in der slavistischen Sprachwissenschaft. Die Welt der Slaven 38(2): 265-297

Lehmann, Volkmar (1998). Eine Kritik der progressiven Funktion als Kriterium aspektueller Verbkategorisierung. Die Welt der Slaven 43: 295-306

Lehmann, Volkmar (1999a). Aspekt. Jachnow, Helmut and Sabine Dönninghaus eds. Handbuch der sprachwissenschaftlichen Russistik und ihrer Grenzdisziplinen. Wiesbaden: Harrassowitz, 214-242

Lehmann, Volkmar (2009a). Formal-funktionale Theorie des russischen Aspekts, https://docs.google.com/document/d/1yoJRTeEd2rrP5nQHMTdHPitzEhD8rbe20o eafSJxsKM/edit?pli=1\# (accessed on March 12th 2020)

Lehmann, Volkmar (2009b). Aspekt und Tempus. Kempgen, Sebastian, Peter Kosta, Tilman Berger and Karl Gutschmidt eds. Die slavischen Sprachen: ein internationales 
Handbuch zu ihrer Struktur, ihrer Geschichte und ihrer Erforschung 1. Berlin: Mouton de Gruyter, 526-556

Lehmann, Volkmar (2010). Der slavische Aspekt im Licht der kognitiven Linguistik. Anstatt, Tanja and Boris Norman, eds. Die slavischen Sprachen im Licht der kognitiven Linguistik. Wiesbaden: Harrassowitz Verlag, 77-99

Ljubešić, Nikola, and Filip Klubička (2014). \{bs,hr,sr\}WaC — Web corpora of Bosnian, Croatian and Serbian. Bildhauer, Felix and Roland Schäfer, eds. Proceedings of the 9th Web as Corpus Workshop (WaC-9). Gothenburg, 29-35

Magner, Thomas F. (1963). Aspectual Variations in Russian and Serbo-Croatian. Language 39(4): 621-630

Maslov, Jurij Sergejevič (1963). Morfologija glagol'nogo vida v sovremennom bolgarskom literaturnom jazyke. Moskva: Izdatel'stvo Akademii nauk SSSR

Maslov, Jurij Sergejevič (1984). Očerki po aspektologii. Leningrad: Izdatel'stvo Leningradskogo universiteta

Matasović, Ranko, and Ljiljana Jojić (eds.) (2002). Hrvatski enciklopedijski rječnik. Zagreb: Novi Liber

Mučnik, Iosif Pavlovič (1966). Razvitie sistemy dvuvidovyh glagolov v russkom jazyke. Voprosyjazykoznanija 1: 61-75

Nübler, Norbert (2002). Vid. Karlík, Petr, Marek Nekula, Jana Pleskalová and Jarmila Bachmannová, eds. Encyklopedickýslovníkčeštiny. Praha: Nakladatelství Lidové noviny, 527-531

Piperski, Alexander (2018). The grammatical profiles of Russian biaspectual verbs. Kopotev, Mikhail, Olga Lyashevskaya and Arto Mustajoki, eds. Quantitative Approaches to the Russian Language. Routledge: London, 115-136

Plotnikova, Ol'ga Sergeevna (1971). Dvuvidovye glagoly inostrannogo proishoždenija v slovenskom literaturnom jazyke. Vestnik Moskovskogo universiteta 1: 28-36

Pöppel, Ernst (1985). Grenzen des Bewußtseins. Über Wirklichkeit und Welterfahrung. Stuttgart: Deutsche Verlags-Anstalt

R Core Team (2016). R: A language and environment for statistical computing. Vienna: R Foundation for Statistical Computing, https://www.R-project.org/ (accessed on March 12th 2020)

Schoorlemmer, Maaike (1995). Participial passive and aspect in Russian. PhD Thesis. Utrecht: Utrecht University. UiL OTS

Silić, Josip, and Ivo Pranjković (2007). Gramatika hrvatskoga jezika. Zagreb: Školska knjiga

Smailagić, Igor (2011). Dvovidni glagoli u hrvatskome i slovenskome jeziku. PhD Thesis. Filozofski fakultet Sveučilišta u Zagrebu

Smiešková, Elena (1961). Dvojvidové slovesá cudzieho pôvodu v slovenčine. Slovenská reč 26(4): 225-230

Stefanowitsch, Anatol (2020). Corpus linguistics: A guide to the methodology. Berlin: Language Science Press. 10.5281/zenodo.3735822

Šeljakin, Mihail Alekseevič (1983). Kategorija vida i sposoby dejstvija russkogo glagola: teoretičeskie osnovy. Tallin: Valgus 
Šonje, Jure, and Anuška Nakić (eds.) (2000). Rječnik hrvatskoga jezika. Zagreb: Leksikografski zavod Miroslav Krleža

Švedova, Natal'ja Jul'evna, Nina Davidovna Arutjunova, Aleksandr Vladimirovič Bondarko, Vjačeslav Vsevolodovič Ivanov, Vladimir Vladimirovič Lopatin, Igor' Stepanovič Uluhanov, and Fedot Petrovič Filin (1980). Russkaja grammatika 1: fonetika, fonologija, udarenie, intonacija, slovoobrazovanie, morfologija. Moskva: Izdatel'stvo Nauka

Tadić, Marko (1998). Raspon, opseg i sastav korpusa suvremenoga hrvatskoga jezika. Filologija, 30-31: 337-347

Tadić, Marko (2002). Building the Croatian National Corpus. LREC2002 II, 441-446. ELRA: Paris-Las Palmas

Toops, Gary H. (1992). Upper Sorbian Prefixal Derivatives and the Question of German Loan Translations. The Slavic and East European Journal 36(1): 17-35

Toporišič, Jože. (2001). Slovenski pravopis. Ljubljana: Slovenska akademija znanosti in umetnosti

Vendler, Zeno (1957). Verbs and times. The Philosophical Review 66: 143-160

Veselý, Luboš (2010). Ke slovesnému vidu v češtině. Naše řeč 93: 113-124

Zaliznjak, Anna Andreevna, and Aleksej Dmitrievič Šmelëv (1997). Lekcii po russkoj aspektologii. München: Verlag Otto Sagner

\section{Akcionalnost i afiksacija hrvatskih dvovidnih glagola u svjetlu formalno-funkcionalne teorije glagolskoga vida}

U slavenskim je jezicima glagolski aspekt obavezna gramatička kategorija, prisutna u infinitivu kao i u svim ostalim glagolskim oblicima kao jedna od dviju oprečnih vrijednosti: perfektivno - imperfektivno. No osim perfektivnih $\mathrm{i}$ imperfektivnih glagola u slavenskim jezicima postoje i dvovidni glagoli. U literaturi se napominje kako infinitiv spomenutih glagola može izraziti obje aspektne vrijednosti, i perfektivnu i imperfektivnu, kao i to da se u kontekstu ostvaruje samo jedna od njih. Međutim, u nekim slučajevima nije baš potpuno jasno koja je aspektna vrijednost ostvarena. Kako bi postigli što veći stupanj komunikacijske jasnoće, izvorni govornici često pribjegavaju afiksaciji dvovidnih glagola pri čemu neki dvovidni glagoli ipak ne podliježu spomenutome procesu. No, kada se govori o aspektnoj afiksaciji općenito, dakle ne samo u kontekstu dvovidnih glagola, svakako treba imati na umu da dio aspektologa tip aspektne afiksacije povezuje s akcionalnim obilježjima (tzv. leksičkim aspektom) glagola.

Upravo potonja pretpostavka uzima se kao polazište ovoga rada u kojemu se proučava afiksacija dvovidnih glagola. Točnije govoreći, ovim se radom nastoji odgovoriti na sljedeće istraživačko pitanje: Razlikuju li se akcionalna obilježja morfološki stabilnih dvovidnih glagola (onih koji ne podliježu aspektnoj afiksaciji) i morfološki nestabilnih dvovidnih glagola (onih koji sudjeluju u afiksaciji)?

Analiza se provodina uzorku od 38 dvovidnih glagola. Uprvomekoraku ispisana su sva pojedina značenja (i varijante značenja) svakoga od analiziranih glagola. U drugome koraku svakome je značenju pripisana leksičko-akcionalna funkcija u skladu s postavkama formalno-funkcionalne teorije slavenskoga aspekta (Lehmann 1999a, 2009a). Posljednji korak uključuje statističku analizu, odnosno primjenu Fisherova testa. Rezultati analize jasno upućuju na to da se akcionalna obilježja stabilnih i nestabilnih dvovidnih glagola značajno razlikuju.

Keywords: biaspectual verbs, actionality, affixation, Fisher exact test, Croatian

Ključne riječi: dvoaspektni glagoli, akcionalnost, afiksacija, Fisherov test, hrvatski jezik 